\title{
Determination of mining equipment motion resistance
}

\author{
Leopold Hrabovský1,*, and Václav Janek ${ }^{2}$ \\ ${ }^{1}$ VŠB - Technical university of Ostrava, Faculty of Mechanical Engineering, Institute of Transport, \\ 17. listopadu 15/2172, 70833 Ostrava - Poruba, Czech Republic \\ ${ }^{2}$ Mining Plant 1, the Lazy mine location, Čs. armády č. p. 1, 73506 Karviná - Doly, Czech Republic
}

\begin{abstract}
The article presents the experimental measurement of the mining equipment motion resistance in the Mining Plant 1, the Lazy mine location district. The procedure of the experimental tests was as follows, one of the transport vessels was fitted with a weight of a known weight. The mining cage was loaded with the weight and pulled up in the traffic pit to the required depth, then the mining equipment was released and, using the IRC rotation speed sensor attached to the rope drum shaft, the travelled trajectory and the instantaneous mining cage speed were recorded with an indirect method. Upon reaching the speed of the transport vessels, a maximum of $3.15 \mathrm{~m} / \mathrm{s}$, the vessels were equipped with the mining equipment brakes and the transport vessels were slowed down to zero speed. From the recorded data in the PC memory, ie initial positions of both transport vessels, travelled trajectory and instantaneous speed values, the values were consequently calculated and added to the stated tables.
\end{abstract}

\section{Introduction}

In a deep mine in the Karviná district, located in the southern part of the Upper Silesian coal basin of the OKD, a.s., in the Mining Plant 1, the Lazy mine location, measurement of motion resistance of the mining equipment No. 1 in the down-cast air shaft No. 5 was carried out with the participation of the INCO engineering s.r.o.

\section{The mining equipment specification}

Mining equipment No. 1 of the down-cast air shaft No. 5, see Fig. 1, of the Mining Plant 1, The Lazy mine location is equipped with a two-drum winder of the Škoda Plzen 2B4016L type, which is driven by an asynchronous engine of $1000 \mathrm{~kW}$ and a nominal revolution of $\mathrm{n}_{\mathrm{m}}=494 \mathrm{rpm}$, see Fig.2.

The mining equipment No. 1 in the down-cast air shaft No. 5 is double-acting with two 2-deck cages adapted for transporting two tipping wagons in succession on each deck of the cage. The diameter of the rope drums of the mining equipment $D_{b}=4 \mathrm{~m}$. The weight of the cage $m_{o}=1720 \mathrm{~kg}$, the weight of the cable load $m_{u}=62 \mathrm{~kg}$. The mining equipment is put to

\footnotetext{
* Corresponding author: leopold.hrabovsky@,vsb.cz
} 
the 9th floor level to a depth of $821.6 \mathrm{~m}$ from the pit bank.

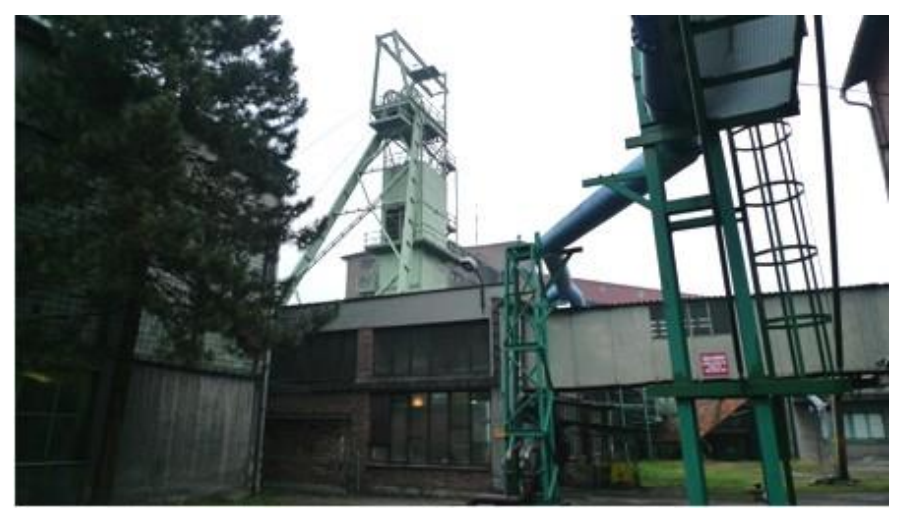

Fig. 1. The mining tower of the down-cast air shaft No. 5 in in the Mining Plant 1, the Lazy Mine location.

\section{The course of experimental tests}

Experimental measurement of the mining equipment motion resistance was carried out under operating conditions, when all the safety features of the winder were ecommissioned. Mining vessels were then set up by a machinist in the down-cast air shaft in a desired position to provide sufficient weight predominance in the branch, which, after releasing the mining equipment, overcomes the static motion resistances and puts the transport vessels in motion.

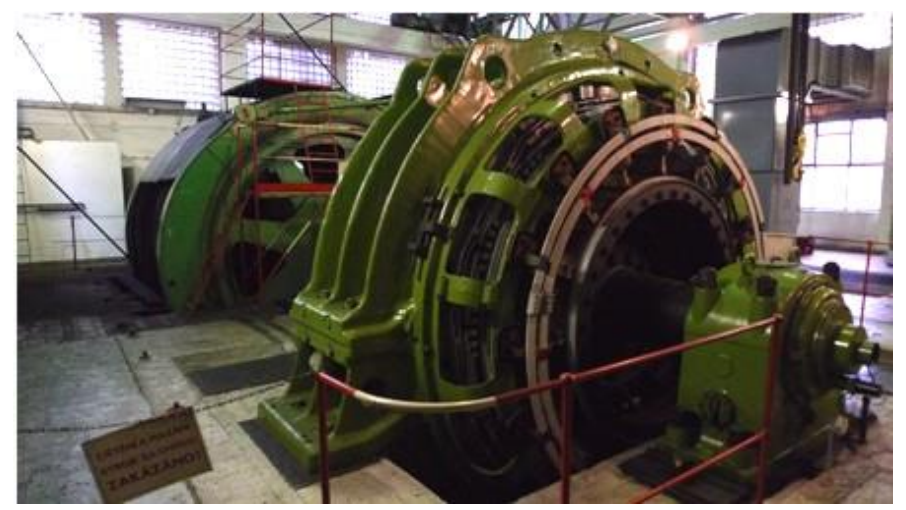

Fig. 2. Two-drum winder of the Škoda 2 B 4016 Type.

In order to obtain the required motion resistance values of the mining equipment No. 1 in the down-cast air shaft No. 5, the data of actual positions of the two transport vessels in the traffic pit were used and were substracted from the console display in the engine room, see Fig.3.

The measurements were carried out under four input conditions, when the transport vessel was fitted with a weight of $0,1000,2000$ and $3000 \mathrm{~kg}$.

The procedure of the experimental tests was as follows - one of the transport vessels was fitted with a weight of a known weight $\mathrm{m}_{\mathrm{z}}[\mathrm{kg}]$. The mining cage was loaded with the weight and pulled up in the traffic pit to the required depth, then the mining equipment was released and, using the IRC rotation speed sensor attached to the rope drum shaft, see Fig. 
4, the travelled trajectory and the instantaneous mining cage speed were recorded with an indirect method. Upon reaching the speed of the transport vessels, a maximum of $3.15 \mathrm{~m} / \mathrm{s}$, the vessels were equipped with the mining equipment brakes and the transport vessels were slowed down to zero speed. From the recorded data in the PC memory, ie initial positions of both transport vessels, travelled trajectory and instantaneous speed values, the values were consequently calculated and added to the stated tables.

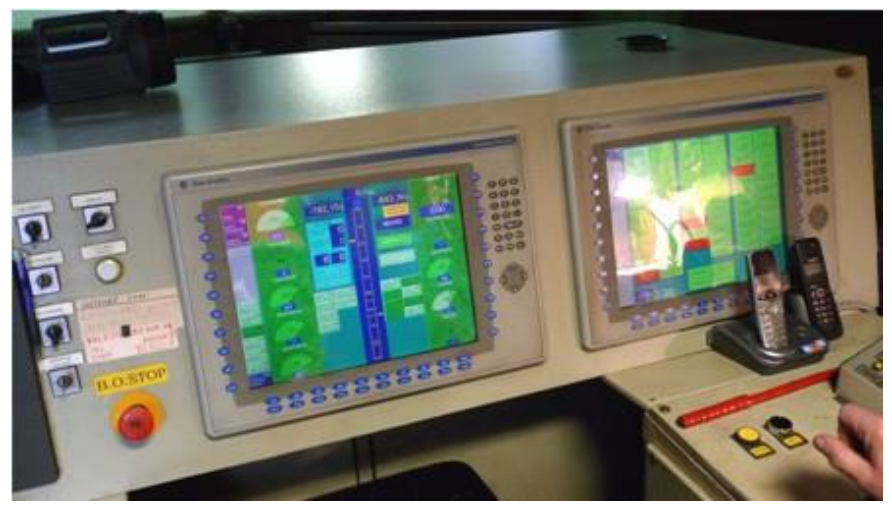

Fig. 3. Computer display installed in the control panel of the engine room of the two-drum winder of the Škoda 2 B 4016 Type.

In order to obtain the values of the speed of the motion and the travelled trajectory of the transport vessels in the transport pit, from which it was subsequently possible to calculate the acceleration of the transport vessels, a measuring sensor, see Fig. 4, was used. It sensed the speed of the mining equipment shaft and via the software, see Fig. 5, it graphically depicted the instantaneous position, speed and acceleration of the transport vessels, see Fig.6. The data scanned from the measuring sensor of the partial measuring was saved in the memory of the portable computer as a data file for subsequent processing.

\section{Evaluation of experimental tests}

The first experiment was based on a number of operational measurements, the results of which were to enable the maximum value of static resistance to be counted against the rotation of the rotating parts of the mining equipment [1], [3].

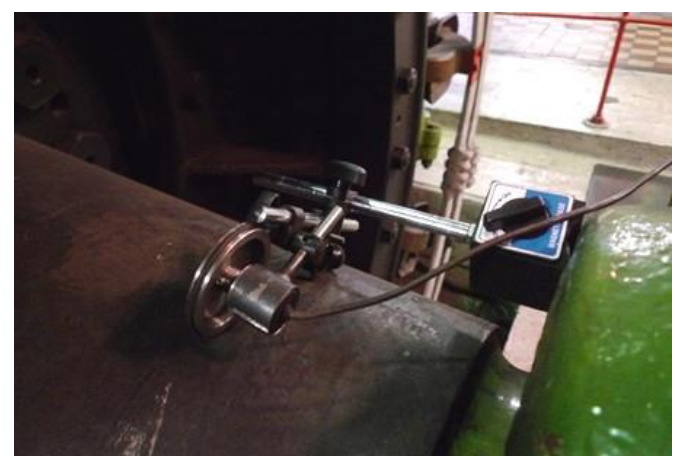

Fig. 4. Measuring sensor sensing the speed of the mining equipment shaft.

The experiment was carried out as follows: a weight of a known weight $m_{z}=[\mathrm{kg}]$ was put into one of the mining cages. The loaded mining cage was lowered to the proper depth 
of the down-cast air shaft, where it was brought to a quiescent condition by the equipment of the winder brake. At the moment when all the sliding and rotating parts of the mining equipment were in a non-moving state, the brake of the winder was released, and it was observed whether the mining cage was starting.

Table 1. Location of transport vessels in the traffic pit.

\begin{tabular}{|c|c|c|c|c|}
\hline Measuring No. & $\begin{array}{c}\text { Depth of 1st } \\
\text { vessel } H_{0}[\mathrm{~m}]\end{array}$ & $\begin{array}{c}\text { Depth of } \\
\text { 2nd vessel } \\
\mathbf{H}_{\mathrm{k}}[\mathrm{m}]\end{array}$ & $\begin{array}{c}\text { Difference } \\
\mathbf{H}_{0}-\mathbf{H}_{\mathbf{k}}= \\
\Delta \mathbf{H}[\mathrm{m}]\end{array}$ & $\begin{array}{l}\text { The weight of } \\
\text { the } 1 \text { st vessel } \\
\text { branch } T_{0}[N]\end{array}$ \\
\hline $\mathrm{F}$ & 444,38 & 380,97 & 63,91 & 32155,42 \\
\hline $\mathrm{G}$ & 443,08 & 382,27 & 60,81 & 32153,97 \\
\hline $\mathrm{H}$ & 445,71 & 379,50 & 66,21 & 32344,82 \\
\hline $\mathrm{I}$ & 465,34 & 359,96 & 105,38 & 33769,36 \\
\hline $\mathrm{J}$ & 468,54 & 356,77 & 111,77 & 34001,58 \\
\hline $\mathrm{K}$ & 423,19 & 402,16 & 21,03 & 30710,56 \\
\hline $\mathrm{L}$ & 432,77 & 392,58 & 40,19 & 31405,78 \\
\hline $\mathrm{M}$ & 443,14 & 382,21 & 60,93 & 31158,32 \\
\hline $\mathrm{N}$ & 450,67 & 374,68 & 75,99 & 32704,77 \\
\hline $\mathrm{O}$ & 460,10 & 364,25 & 95,85 & 33389,09 \\
\hline \multirow[t]{2}{*}{$\mathrm{P}$} & 470,00 & 355,35 & 114,65 & 34107,53 \\
\hline & $\begin{array}{l}\text { The weight of } \\
\text { the } 2 \text { st vessel } \\
\text { branch } T_{k}[N]\end{array}$ & $\begin{array}{c}\text { Difference } \\
T_{0}-T_{k}= \\
O_{p}[N]\end{array}$ & $\begin{array}{c}\text { Weight } \\
\text { excess x } \\
{[\mathrm{kg}]}\end{array}$ & $\begin{array}{l}\text { Moment on the } \\
\text { shaft } M_{b}[\mathrm{Nm}]\end{array}$ \\
\hline $\mathrm{F}$ & 27743,21 & 4505,10 & 469,23 & 9203,20 \\
\hline $\mathrm{G}$ & 27741,03 & 4412,93 & 449,99 & 8825,87 \\
\hline $\mathrm{H}$ & 27540,02 & 4804,81 & 489,95 & 9609,61 \\
\hline I & 26122,00 & 7647,34 & 779,81 & 15294,69 \\
\hline $\mathrm{J}$ & 25890,52 & 8111,06 & 827,10 & 16222,12 \\
\hline $\mathrm{K}$ & 29184,43 & 1526,13 & 155,61 & 3052,26 \\
\hline $\mathrm{L}$ & 28481,22 & 2916,56 & 297,41 & 5833,11 \\
\hline $\mathrm{M}$ & 27736,68 & 4421,64 & 450,88 & 8843,28 \\
\hline $\mathrm{N}$ & 27190,23 & 5514,53 & 562,33 & 11029,07 \\
\hline $\mathrm{O}$ & 26433,33 & 6955,76 & 709,29 & 13911,52 \\
\hline $\mathrm{P}$ & 25787,47 & 8320,66 & 848,41 & 16640,12 \\
\hline
\end{tabular}

In Table 1 - operating condition where the transport vessels were not fitted with any weight, ie. $m_{z}=0 \mathrm{~kg}$, the values of the initial positions of the transport vessels $H_{o}[\mathrm{~m}]$ and $\mathrm{H}_{\mathrm{k}}[\mathrm{m}]$ are provided in the first and second column.

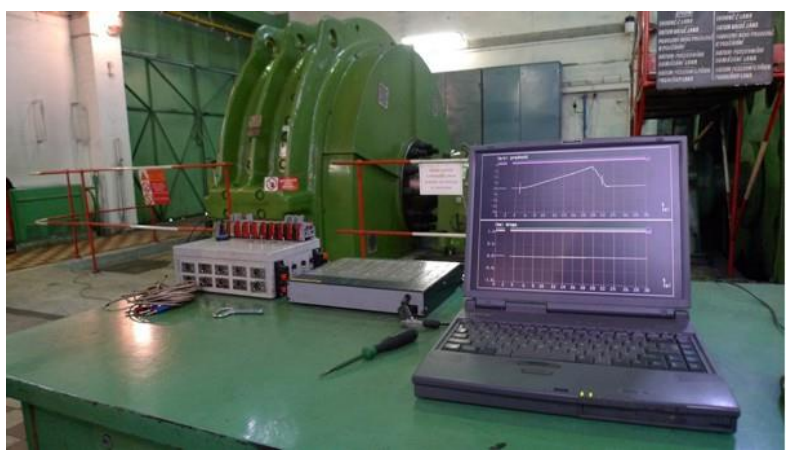

Fig. 5. Software enabling graphical depiction of the data obtained from the measuring sensor on the portable PC display. 
From the known weight value of the mining rope $\left(\mathrm{m}_{\mathrm{L}}=7.4 \mathrm{~kg} / \mathrm{m}\right)$, the values of the traffic vessels positions $\mathrm{H}_{\mathrm{o}}[\mathrm{m}]$ and $\mathrm{H}_{\mathrm{k}}[\mathrm{m}]$ in the transport pit and weights of the transport vessels $\left(m_{o}[\mathrm{~m}]\right.$ and $\left.m_{k}[\mathrm{~m}]\right)$, the static loads $\mathrm{T}_{\mathrm{o}}[\mathrm{N}]$ and $\mathrm{T}_{\mathrm{k}}[\mathrm{N}]$ were calculated in both branches of the mining rope, see the relation (1) and (2), calculated for the measurement No. P, see table 1 .

$$
\begin{array}{r}
\mathrm{T}_{\mathrm{o}}=\left(\mathrm{m}_{\mathrm{o}}+\mathrm{m}_{\mathrm{z}}+\mathrm{H}_{\mathrm{o}} \cdot \mathrm{m}_{\mathrm{L}}\right) \cdot \mathrm{g}=\left(\mathrm{m}_{\mathrm{o}}+0+470 \cdot 7,4\right) \cdot 9,81=\mathrm{m}_{\mathrm{o}} \cdot \mathrm{g}+34107,53 \mathrm{~N} \\
\mathrm{~T}_{\mathrm{k}}=\left(\mathrm{m}_{\mathrm{k}}+\mathrm{H}_{\mathrm{k}} \cdot \mathrm{m}_{\mathrm{L}}\right) \cdot \mathrm{g}=\left(\mathrm{m}_{\mathrm{k}}+355,35 \cdot 7,4\right) \cdot \mathrm{g}=\mathrm{m}_{\mathrm{k}} \cdot \mathrm{g}+25787,47 \mathrm{~N}
\end{array}
$$

where:

$\mathrm{m}_{\mathrm{z}}[\mathrm{kg}]$ - the weights installed in the mining vessel,

$\mathrm{m}_{\mathrm{o}}[\mathrm{kg}]$ - weight of the mining vessel in the left branch of the mining equipment,

$\mathrm{m}_{\mathrm{k}}[\mathrm{kg}]$ - weight of the mining vessel in the right branch of the mining equipment,

$\mathrm{m}_{\mathrm{L}}[\mathrm{kg} / \mathrm{m}]$ - weight of $1 \mathrm{~m}$ of the length of the mining rope.

A $37.5 \mathrm{~mm}$ diameter mining rope with a weight of $7.4 \mathrm{~kg}$ was used for the aforesaid mining equipment.

Assuming the two mining vessels, see Fig. 8, have the same weight, ie. $m_{o}=m_{k}=m_{o k}$ $[\mathrm{kg}]$ the difference of the static loads was To $[\mathrm{N}]-\mathrm{T}_{\mathrm{K}}[\mathrm{N}]$, see (3) and table 1 , the value was set, see (3),

$$
\begin{aligned}
\mathrm{T}_{\mathrm{o}}-\mathrm{T}_{\mathrm{k}} & =\left(\mathrm{m}_{\mathrm{ok}}+\mathrm{H}_{\mathrm{o}} \cdot \mathrm{m}_{\mathrm{L}}\right) \cdot \mathrm{g}-\left(\mathrm{m}_{\mathrm{ok}}+\mathrm{H}_{\mathrm{k}} \cdot \mathrm{m}_{\mathrm{L}}\right) \cdot \mathrm{g}=\left(\mathrm{H}_{\mathrm{o}}-\mathrm{H}_{\mathrm{k}}\right) \cdot \mathrm{m}_{\mathrm{L}} \cdot \mathrm{g}=\Delta \mathrm{H} \cdot \mathrm{m}_{\mathrm{L}} \cdot \mathrm{g}= \\
& =114,65 \cdot 7,4 \cdot 9,81=8320,66 \mathrm{~N}
\end{aligned}
$$

which is the static motion resistance $\mathrm{O}_{p}[\mathrm{~N}]$. The relation (3) expresses the rope drum $\mathrm{O}_{p}$ $[\mathrm{N}]$ rotation static resistance, which is defined by the frictional force $\mathrm{T}[\mathrm{N}]$ acting in the sliding bearings of the shaft of the rope drum, see the relation (4).

$$
\mathrm{O}_{\mathrm{po}}=\mathrm{T}=\mathrm{m}_{\mathrm{b}} \cdot \mathrm{g} \cdot \mathrm{f}_{\mathrm{c}}[\mathrm{N}]
$$

The friction coefficient $f_{\tilde{c}}[-]$ is proportional to the vertical force (ie the weight of the rope drum) and generally indicates which force should be used to move one body against the other one. Depending on whether the body moves from a rest position or only stays in motion, it is possible to distinguish between static friction coefficients and sliding friction [4], [5].

For sliding bearings of the rope drum, it is assumed that the friction coefficient of the contact surfaces at acceleration (gap semi-dry friction) is $f_{\check{c}}=0.1$ to 0.25 at rpm above 0.5 rps, and $\mathrm{f}_{\check{c}}=0.01$ to 0.001 .

From the relation (1), it is possible to determine the own weight of the rotating parts of the winder, including the rope drum $\mathrm{m}_{\mathrm{rb}}[\mathrm{kg}]$, see the relation (5).

$$
\mathrm{O}_{\mathrm{po}}=\mathrm{T}=\mathrm{m}_{\mathrm{rb}} \cdot \mathrm{g} \cdot \mathrm{f}_{\check{\mathrm{c}}} \Rightarrow \mathrm{m}_{\mathrm{rb}}=\frac{\mathrm{T}}{\mathrm{f}_{\check{c}} \cdot \mathrm{g}}[\mathrm{kg}]
$$

According to the Table 1, it is possible to define that the amount of the rope drum rotation resistance $\mathrm{O}_{\mathrm{p}}[\mathrm{N}]$ increases depending on the size of the difference in the $\Delta H[\mathrm{~m}]$ position of transport vessels in the traffic pit. At some point, when the rope drum rotation resistance $\mathrm{O}_{p}[\mathrm{~N}]$ is exceeded, ie. the frictional resistance of the sliding bearings of the rope drum, the traffic vessels move in motion due to the prevalence of load in the given branch of the mining equipment [6].

Comparing the Table 1 values on the positions of the two transport vessels for 
measuring no. $\mathrm{P}$ (where the friction resistance of the rope drum sliding bearings have not been overcome by the weight predominance) with the position values of the two transport vessels in the Table 3 for measuring no. L1 (where the friction resistance of the rope drum sliding bearings have already been overcome by the weight predominance), it is possible to conclude that the motion resistance is $\mathrm{O}_{\mathrm{p}}=8320.66 \mathrm{~N}$.

Using Fig. 8, the relation (6) applies to the friction force $\mathrm{T}[\mathrm{N}]$ in the sliding bearings.

$$
\text { T. } \mathrm{r}_{\check{c}}=\mathrm{O}_{\mathrm{p}} \cdot \mathrm{R}_{\mathrm{b}} \Rightarrow \mathrm{T}=\frac{\mathrm{O}_{\mathrm{p}} \cdot \mathrm{R}_{\mathrm{b}}}{\mathrm{r}_{\check{c}}}=\frac{8320,66 \cdot 2}{0,15}=\frac{16641,32}{0,15}=110942,13 \mathrm{~N}=110,94 \mathrm{kN}
$$

where $r_{\check{c}}[\mathrm{~mm}]$ - the radius of the rope drum shaft, pin diameter $\mathrm{d}_{\check{c}}=300 \mathrm{~mm}$.

Using the relation (2), while selecting the value of the friction coefficient $f_{\check{c}}=0,25$ (for steel-bronze contact surfaces) [2, page 34] and the relation (6) for the frictional force $\mathrm{T}[\mathrm{N}$ ] in the rope drum shaft sliding bearings, it is possible to determine the weight of the rotating parts of the winder, including the rope drum, according to the relation (7).

$$
\mathrm{m}_{\mathrm{rb}}=\frac{\mathrm{T}}{\mathrm{f}_{\mathrm{c}} \cdot \mathrm{g}}=\frac{110942,13}{0,25 \cdot 9,81}=\frac{110942,13}{2,45}=45282,5 \mathrm{~kg}=45,28 \mathrm{t}
$$

From the drawing documentation of the mining equipment in question, it was found out that the actual weight of the winder shaft is $m_{h}=8600 \mathrm{~kg}$, the weight of both drums $m_{2 B}=$ $29560 \mathrm{~kg}$ and the weight of the rotor of the driving engine $\mathrm{m}_{\mathrm{rm}}=7000 \mathrm{~kg}$. Actual weight $\mathrm{m}_{\mathrm{s}}$ [kg] see (8).

$$
\mathrm{m}_{\mathrm{s}}=\mathrm{m}_{\mathrm{h}}+\mathrm{m}_{2 \mathrm{~b}}+\mathrm{m}_{\mathrm{s}}=8600+29560+7000=45160 \mathrm{~kg}=45,16 \mathrm{t}
$$

By calculation determined weight $\mathrm{mrb}[\mathrm{kg}]$ of the rotating parts of the winder, see the

\begin{tabular}{|c|c|c|c|c|}
\hline \multicolumn{5}{|c|}{ Weight of the weights in mining vessel $m_{z}=1000 \mathrm{~kg}$} \\
\hline Measuring No. & $\begin{array}{c}\text { Depth of 1st } \\
\text { vessel } H_{0}[\mathrm{~m}]\end{array}$ & $\begin{array}{c}\text { Depth of } \\
\text { 2nd vessel } \\
\mathrm{H}_{\mathrm{k}}[\mathrm{m}]\end{array}$ & $\begin{array}{c}\text { Difference } \\
\mathbf{H}_{0}-\mathbf{H}_{\mathrm{k}}[\mathrm{m}]\end{array}$ & $\begin{array}{c}\text { Weight of 1st vessel } \\
\text { branch } T_{0}[N]\end{array}$ \\
\hline \multirow{3}{*}{$\mathrm{R}$} & 399,20 & 426,21 & $-27,01$ & 38776,28 \\
\hline & $\begin{array}{c}\text { Weight of } \\
\text { 2nd vessel } \\
\text { branch } T_{k}[N]\end{array}$ & $\begin{array}{l}\text { Difference } \\
T_{0}-T_{k}[N]\end{array}$ & $\begin{array}{c}\text { Weight } \\
\text { excess } \mathrm{x}[\mathrm{kg}]\end{array}$ & $\begin{array}{l}\text { Moment on the shaft } \\
\mathrm{M}_{\mathrm{b}}[\mathrm{Nm}]\end{array}$ \\
\hline & 30929,72 & 7846,56 & 800,13 & 16693,11 \\
\hline \multicolumn{5}{|c|}{ Weight of the weights in mining vessel $m_{z}=3000 \mathrm{~kg}$} \\
\hline \multirow{3}{*}{$\mathrm{D}$} & 181,64 & 643,87 & 462,23 & 42601,20 \\
\hline & $\begin{array}{c}\text { Weight of } \\
\text { 2nd vessel } \\
\text { branch } T_{k}[N]\end{array}$ & $\begin{array}{l}\text { Difference } \\
\mathrm{T}_{\mathrm{o}}-\mathrm{T}_{\mathrm{k}}[\mathrm{N}]\end{array}$ & $\begin{array}{c}\text { Weight } \\
\text { excess } \mathrm{x}[\mathrm{kg}]\end{array}$ & $\begin{array}{l}\text { Moment on the shaft } \\
\mathrm{M}_{\mathrm{b}}[\mathrm{Nm}]\end{array}$ \\
\hline & 46725,14 & 4123,72 & 420,50 & 8247,43 \\
\hline
\end{tabular}
relation (7), corresponds to the actual weight $\mathrm{m}_{\mathrm{s}}[\mathrm{kg}]$, see the relation (8).

Table 2. Position of transport vessels in the traffic pit.

In Table 2, there are values for the operating condition, when the transport vessels were fitted with a weight, ie. $\mathrm{m}_{\mathrm{z}}=1000 \mathrm{~kg}$ and $3000 \mathrm{~kg}$.

In Table 3 in the first two columns, there are stated the $\mathrm{H}_{\mathrm{o}}[\mathrm{m}]$ and $\mathrm{H}_{\mathrm{k}}[\mathrm{m}]$ positions, taken from the console display in the winder engine room where both transport vessels were located at the moment of the beginning of the experimental measuring [7]. From the data files (saved in the PC memory in the partial experimental measuring L1 and L12), the time $t_{1}[s]$ (the time at which the transport vessels have just begun to move) and the time $t_{2}$ [s] (the time at which the traffic vessels were moving in the pre-selected maximum speed in $[\mathrm{m} / \mathrm{s}]$. After the speed value was reached in $[\mathrm{m} / \mathrm{s}]$, the mining equipment was slowed down by the machinist.) By the difference of time $t_{2}-t_{1}[s]$, the travel time ie $t_{j}[s]$ of the mining 
vessels was defined (see third column in Table 3). Times $t_{1}[s]$ and times $t_{2}$ [s] can also be subtracted from graphical records of the partial experimental measuring, see Figure 6.

For the experimentally obtained data saved in the PC, ie. the speed of the winder shaft in the course of time, and from the graphical records, see Fig. 6, it was possible to determine the total motion resistance of the $\mathrm{O}_{\mathrm{pa}}[\mathrm{N}]$ and $\mathrm{O}_{\mathrm{pb}}[\mathrm{N}]$ of the rotating parts of the two-drum winder, see Table 3.

From the data files, see Fig. 9, the value of the travelled trajectory $\mathrm{h}[\mathrm{m}]$ by the mining vessel at the time $t j=t_{2}-t_{1}[s]$ (see the fourth column in Table 3) was subtracted at the time $\mathrm{t}_{2}[\mathrm{~m}]$ and the maximum speed achieved in $[\mathrm{m} / \mathrm{s}]$ (see the fifth column in Table 3 ). The travelled trajectory $\mathrm{h}[\mathrm{m}]$ and the maximum speed achieved in $[\mathrm{m} / \mathrm{s}]$ can also be subtracted from the graphical reports of the partial experimental measuring, see Fig. 6.

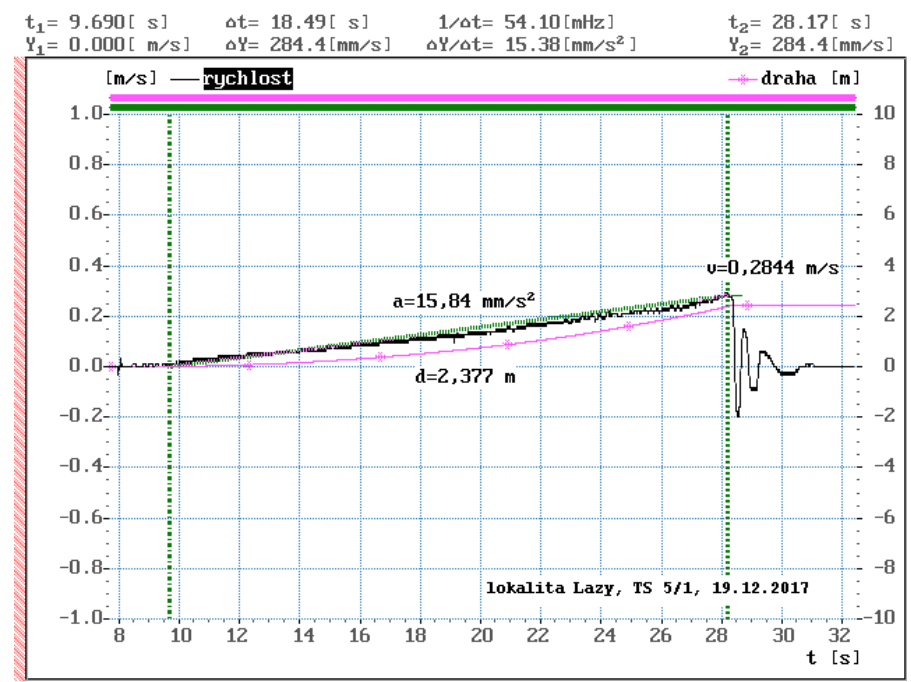

Fig. 6. Graphic depiction of the speed, acceleration, and trajectory course on the portable PC display.

From the saved data, in the data files on the PC disk obtained from the experimental tests (file L1.dat to L12.dat), the course of motion speed in $[\mathrm{m} / \mathrm{s}]$ and the travelled trajectory $\mathrm{h}[\mathrm{m}]$ of the transport vessels, see Fig. 7, was described in the MS Excel program (for each partial experimental measuring.).

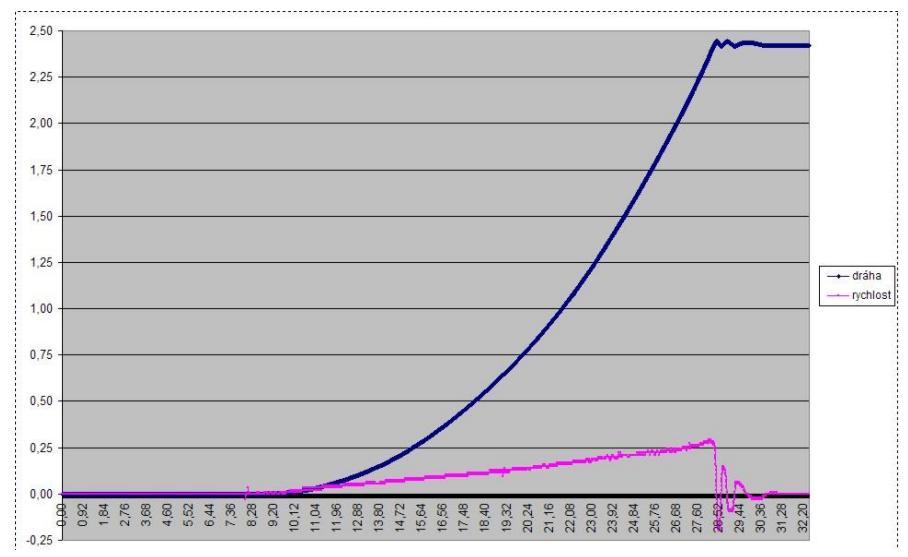

Fig. 7. Graphical depiction of speed and trajectory progression created in MS Excel from the L1.dat data file. 
At the moment when the left mining vessel moving is due to its actual weight of Go = mo. $g[N]$ and the rope weight $G_{L o}=m_{L} . H_{o} . g[N]$, see Fig. 8, the motion resistance $O_{p}[N]$ and the weight of the right branch of the mining vessel $T_{k}[N]$ is overcome.

The weight of the right mining vessel $T_{k}[N]$ is determined by the sum of the actual weight of the right mining vessel $G_{k}=m_{k}$. $g[N]$, rope weight $G_{L k}=m_{L} \cdot H_{k} \cdot g[N]$. The actual weight of the right vessel $m_{k}[\mathrm{~kg}]$ is higher than the weight of the left vessel $\mathrm{m}_{\mathrm{o}}[\mathrm{kg}]$ by the value $m_{x}[\mathrm{~kg}]$. It is therefore possible to determine the actual weight of the right mining vessel as $\mathrm{G}_{\mathrm{k}}=\mathrm{m}_{\mathrm{k}} \cdot \mathrm{g}=\left(\mathrm{m}_{\mathrm{o}}+\mathrm{m}_{\mathrm{x}}\right) \cdot \mathrm{g}[\mathrm{N}]$.
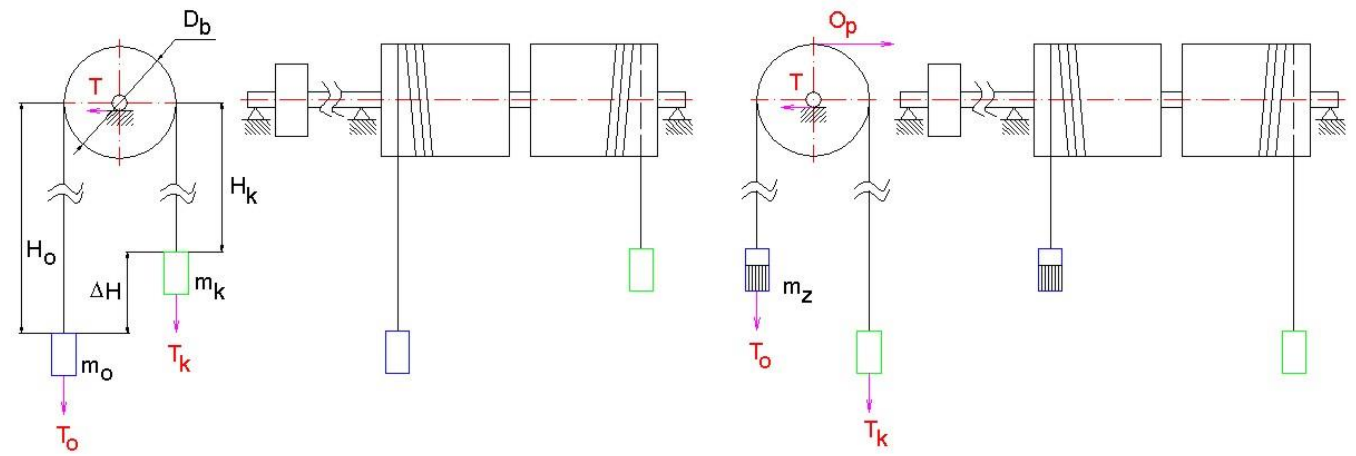

Fig. 8. Schematic depiction of the two-drum mining equipment device.

Since the exact weight $m_{x}[\mathrm{~kg}]$ is not known, calculations will be made for the two following cases:

a) $m_{x}=0 \mathrm{~kg}$, where $m_{k}=m_{0}+m_{x}=m_{o}[\mathrm{~kg}]$,

b) $\mathrm{m}_{\mathrm{x}}=450 \mathrm{~kg}$, where $\mathrm{m}_{\mathrm{k}}=\mathrm{m}_{\mathrm{o}}+\mathrm{m}_{\mathrm{x}}=\mathrm{m}_{\mathrm{o}}+450[\mathrm{~kg}]$.

In case of a), at the moment of starting the left mining vessel, it is possible to determine a balance equation of occurring load in the two branches of the mining equipment (9), from which the value of the total motion resistance $\mathrm{O}_{p}[\mathrm{~N}]$ can be determined by a modification, see the relation (10).

$$
\begin{gathered}
\mathrm{m}_{\mathrm{o}} \cdot \mathrm{g}+\left(\mathrm{H}_{\mathrm{o}} \cdot \mathrm{m}_{\mathrm{L}}\right) \cdot \mathrm{g}=\mathrm{O}_{\mathrm{pa}}+\mathrm{m}_{\mathrm{o}} \cdot \mathrm{g}+\left(\mathrm{H}_{\mathrm{k}} \cdot \mathrm{m}_{\mathrm{L}}\right) \cdot \mathrm{g}[\mathrm{N}] \\
\left(\mathrm{H}_{\mathrm{o}}-\mathrm{H}_{\mathrm{k}}\right) \cdot \mathrm{m}_{\mathrm{L}} \cdot \mathrm{g}=\mathrm{O}_{\mathrm{pa}}[\mathrm{N}]
\end{gathered}
$$

\begin{tabular}{|c|c|c|c|c|c|c|c|c|c|}
\hline "t $[s] " \quad$ "U1 $[V]$ & "U2N]" "U3RT" & "U4 $\left[V^{\prime}\right]$ & "droga $[m] " \quad$ "p & "pr'dkożt"lm/s" "pr & szenie[m/sý] & "U1"U2 $\left.{ }^{*} V^{*}\right]^{2}$ & "U1*U2 $\left.{ }^{*} V\right]^{\prime}$ & "zn.1" "zr & \\
\hline $0.0000 E+00$ & $0.000 E+00$ & $-3.897 E-04$ & $4 \quad 1.169 E-03$ & $-4.670 E-03$ & $0.000 E+00$ & $0.000 E+00$ & $0.000 E+00$ & $0.000 E+00$ & $0.000 E+00$ \\
\hline $5.0000 E-03$ & $0.000 E+00$ & $-1.948 E-03$ & $2728 E-03$ & $1.557 E-03$ & $0.000 E+00$ & $0.000 E+00$ & $0.000 E+00$ & $0.000 E+00$ & $0.000 E+00$ \\
\hline $1.0000 E-02$ & $0.000 E+00$ & $-3.897 E-04$ & $1.169 E-03$ & $1.557 E-03$ & $0.000 E+00$ & $0.000 E+00$ & $0.000 E+00$ & $0.000 E+00$ & $0.000 E+00$ \\
\hline $1.5000 E-02$ & $-1.560 E-03$ & $-3.897 E-04$ & $1.169 E-03$ & $0.000 E+00$ & $0.000 E+00$ & $0.000 E+00$ & $0.000 E+00$ & $6.079 E-07$ & $6.079 E-07$ \\
\hline $2.0000 E-02$ & $-1.560 E-03$ & $-1.948 E-03$ & $-3.898 E-04$ & $0.000 E+00$ & $0.000 E+00$ & $0.000 E+00$ & $0.000 E+00$ & $3.040 E-06$ & $3.040 E-06$ \\
\hline $2.5000 \mathrm{E}-02$ & $0.000 E+00$ & $-3.897 E-04$ & 4.287E-03 & $3.113 E-03$ & $0.000 E+00$ & $0.000 E+00$ & $0.000 E+00$ & $0.000 E+00$ & $0.000 E+00$ \\
\hline $3.0000 E-02$ & $0.000 E+00$ & $-3.897 E-04$ & $1.169 E-03$ & $-1.557 E-03$ & $0.000 E+00$ & $0.000 E+00$ & $0.000 E+00$ & $0.000 E+00$ & $0.000 E+00$ \\
\hline 3.5000E-02 & $-1.560 E-03$ & 1.169E-03 & $1.169 E-03$ & $-1.557 E-03$ & $0.000 E+00$ & $0.000 E+00$ & $0.000 E+00$ & $-1.824 E-06$ & $-1.824 E-06$ \\
\hline 4.0000E-02 & $0.000 E+00$ & $-3.897 E-04$ & $1.169 E-03$ & $-3.113 E-03$ & $0.000 E+00$ & $0.000 E+00$ & $0.000 E+00$ & $0.000 E+00$ & $0.000 E+00$ \\
\hline 4.5000E-02 & $0.000 E+00$ & $-3.897 E-04$ & $2.728 E-03$ & $3.113 E-03$ & $0.000 E+00$ & $0.000 E+00$ & $0.000 E+00$ & $0.000 E+00$ & $0.000 E+00$ \\
\hline $5.0000 E-02$ & $0.000 E+00$ & $-3.897 E-04$ & $1.169 E-03$ & $-4.670 E-03$ & $0.000 E+00$ & $0.000 E+00$ & $0.000 E+00$ & $0.000 E+00$ & $0.000 E+00$ \\
\hline $5.5000 E-02$ & $0.000 E+00$ & $-3.897 E-04$ & $2728 E-03$ & $1.557 E-03$ & $0.000 E+00$ & $0.000 E+00$ & $0.000 E+00$ & $0.000 E+00$ & $0.000 E+00$ \\
\hline $6.0000 E-02$ & $0.000 E+00$ & $-3.897 E-04$ & $2.728 E-03$ & $0.000 E+00$ & $0.000 E+00$ & $0.000 E+00$ & $0.000 E+00$ & $0.000 E+00$ & $0.000 E+00$ \\
\hline $6.5000 \mathrm{E}-02$ & $0.000 E+00$ & 1.169E-03 & $2728 E-03$ & $1.557 E-03$ & $0.000 E+00$ & $0.000 E+00$ & $0.000 E+00$ & $0.000 E+00$ & $0.000 E+00$ \\
\hline $7.0000 E-02$ & $0.000 E+00$ & $-3.897 E-04$ & $2.728 E-03$ & $1.557 E-03$ & $0.000 E+00$ & $0.000 E+00$ & $0.000 E+00$ & $0.000 E+00$ & $0.000 E+00$ \\
\hline $7.5000 E-02$ & $0.000 E+00$ & $-3.897 E-04$ & $2728 E-03$ & $-1.557 E-03$ & $0.000 E+00$ & $0.000 E+00$ & $0.000 E+00$ & $0.000 E+00$ & $0.000 E+00$ \\
\hline $8.0000 E-02$ & $0.000 E+00$ & $-1.948 E-03$ & 1.169E-03 & $-3.113 E-03$ & $0.000 E+00$ & $0.000 E+00$ & $0.000 E+00$ & $0.000 E+00$ & $0.000 E+00$ \\
\hline $8.5000 E-02$ & $0.000 E+00$ & $-3.897 E-04$ & $-1.949 E-03$ & $1.557 E-03$ & $0.000 E+00$ & $0.000 E+00$ & $0.000 E+00$ & $0.000 E+00$ & $0.000 E+00$ \\
\hline $9.0000 E-02$ & $0.000 E+00$ & $-3.897 E-04$ & $1.169 E-03$ & $-1.557 E-03$ & $0.000 E+00$ & $0.000 E+00$ & $0.000 E+00$ & $0.000 E+00$ & $0.000 E+00$ \\
\hline $9.5000 E-02$ & $0.000 E+00$ & $-3.897 E-04$ & $1.169 E-03$ & $-1.557 E-03$ & $0.000 E+00$ & $0.000 E+00$ & $0.000 E+00$ & $0.000 E+00$ & $0.000 E+00$ \\
\hline 1.0000E-01 & $0.000 E+00$ & $-1.948 E-03$ & $-3.898 E-04$ & $3.113 E-03$ & $0.000 E+00$ & $0.000 E+00$ & $0.000 E+00$ & $0.000 E+00$ & $0.000 E+00$ \\
\hline 1.0500E-01 & $0.000 E+00$ & $-3.897 E-04$ & 1.169E-03 & $4.670 E-03$ & $0.000 E+00$ & $0.000 E+00$ & $0.000 E+00$ & $0.000 E+00$ & $0.000 E+00$ \\
\hline
\end{tabular}

where $\mathrm{O}_{\mathrm{pa}}[\mathrm{N}]$ is the total motion resistance to movement.

Fig. 9. Data series saved into data files L1 (up to L12).dat obtained by experimental tests. 
In case of b), at the moment of starting the left mining vessel, it is possible to determine a balance equation of occurring load in the two branches of the mining equipment (11), from which the value of the total motion resistance Op [N] can be determined by a modification, see the relation (12).

Assuming that both mining vessels are of the same weight, ie. $\mathrm{m}_{\mathrm{o}}=\mathrm{m}_{\mathrm{k}}[\mathrm{kg}]$, it is possible to determine, for the known values (see Table 3 lineL1), the value of the mining equipment total motion resistance $\mathrm{O}_{\mathrm{pa}}[\mathrm{N}]$, according to the relation (10), see relation (13).

$$
\mathrm{O}_{\mathrm{pa}}=\left(\mathrm{H}_{\mathrm{o}}-\mathrm{H}_{\mathrm{k}}\right) \cdot \mathrm{mL} \cdot \mathrm{g}=(471,16-353,14) \cdot 7,4 \cdot 9,81=8564,62 \mathrm{~N}
$$

Assuming that the right mining vessel has a weight, i.e., $\mathrm{m}_{\mathrm{k}}=\mathrm{m}_{\mathrm{o}}+\mathrm{m}_{\mathrm{x}}[\mathrm{kg}]$, where the weight predominance over the weight of the left transport vessel is determined as $m_{x}=450$ $\mathrm{kg}$, it is possible, for the known values (see Table 3 line L1), to determine the value of the mining equipment total motion resistance $\mathrm{O}_{\mathrm{pb}}[\mathrm{N}]$, according to the relation (12), see the relation (14).

$$
\mathrm{O}_{\mathrm{pb}}=\left(\mathrm{H}_{\mathrm{o}}-\mathrm{H}_{\mathrm{k}}\right) \cdot \mathrm{m}_{\mathrm{L}} \cdot \mathrm{g}-\mathrm{m}_{\mathrm{x}} \cdot \mathrm{g}=(471,16-353,14) \cdot 7,4 \cdot 9,81-450 \cdot 9,81=4151,63 \mathrm{~N}
$$

According to the basic motion equation [1, p. 40], the instantaneous driving force $\mathrm{F}[\mathrm{N}]$, see the relation (15) determined by the change of momentum theorem, ie that the impulse of force is equal to the time change of the momentum of the body, is determined by the sum of all static resistances $\mathrm{F}_{\mathrm{s}}[\mathrm{N}]$ and the force needed to accelerate sliding and rotating masses $\mathrm{F}_{\mathrm{d}}[\mathrm{N}][8]$.

$$
\mathrm{F}-\mathrm{F}_{\mathrm{s}}-\mathrm{m} \cdot \frac{\mathrm{dv}}{\mathrm{dt}}=0[\mathrm{~N}]
$$

The weight $\mathrm{m}[\mathrm{kg}]$ to determine the inertia force $\mathrm{F}_{\mathrm{d}}[\mathrm{N}]$ comprises of the total weight of the sliding masses $\mathrm{mp}[\mathrm{kg}]$ and the rotating masses reduced to the tensile element $\mathrm{m}_{\mathrm{r}}[\mathrm{kg}]$.

$$
\mathrm{F}=\mathrm{F}_{\mathrm{s}}+\mathrm{F}_{\mathrm{d}}=\mathrm{F}_{\mathrm{s}}+\mathrm{F}_{\mathrm{dp}}+\mathrm{F}_{\mathrm{dr}}=\mathrm{F}_{\mathrm{s}}+\mathrm{m}_{\mathrm{p}} \cdot \frac{\mathrm{dv}}{\mathrm{dt}}+\frac{\mathrm{J}}{\mathrm{R}^{2}} \cdot \frac{\mathrm{dv}}{\mathrm{dt}}[\mathrm{N}]
$$

The total rope drum rotation resistance $\mathrm{O}_{\mathrm{p}}[\mathrm{N}]$ as the friction resistance in the sliding bearing of the rope drum shaft was determined in the Table 1 (for measuring No. L) at the value $\mathrm{T}=\mathrm{O}_{\mathrm{p}}=8320,66 \mathrm{~N}$, which is one of the components of the static resistance $\mathrm{F}_{\mathrm{s}}[\mathrm{N}]$.

If the instantaneous driving force $\mathrm{F}[\mathrm{N}]$ putting the transport vessels of the mining device in motion is given by the value stated in relation (30) and the static resistance $\mathrm{F}_{\mathrm{S}}[\mathrm{N}]$, the value $\mathrm{O}_{\mathrm{po}}=8320,66 \mathrm{~N}$, the relation (16) can be modified into the form of (17), and placing a component of the inertial force of the sliding masses $F_{d p}[N]$ into it, expressed according to the relation (18).

$$
\mathrm{F}-\mathrm{F}_{\mathrm{s}}=\left(\mathrm{F}_{\mathrm{d}}=\mathrm{F}_{\mathrm{dp}}+\mathrm{F}_{\mathrm{dr}}\right)=\mathrm{F}_{\mathrm{dp}}+\frac{\mathrm{J}}{\mathrm{R}^{2}} \cdot \frac{\mathrm{dv}}{\mathrm{dt}} \Rightarrow 8564,62-8320,66=\mathrm{F}_{\mathrm{dp}}+\frac{\mathrm{J}}{\mathrm{R}^{2}} \cdot \frac{\mathrm{dv}}{\mathrm{dt}}[\mathrm{N}](17
$$

Where:

$$
F_{d p}=m_{p} \cdot a=m_{p} \cdot \frac{d v}{d t}=m_{p} \cdot \frac{v_{2}-v_{1}}{t_{2}-t_{1}}=m_{p} \cdot \frac{v}{t_{j}}[N]
$$

The total weight of the sliding masses $\mathrm{m}_{\mathrm{p}}[\mathrm{kg}]$ given in the relations (15) to (17) can be expressed according to the relation (19) using the relations (1) and (2). 


$$
\mathrm{m}_{\mathrm{p}}=\frac{\mathrm{T}_{\mathrm{o}}}{\mathrm{g}}+\frac{\mathrm{T}_{\mathrm{k}}}{\mathrm{g}}=\mathrm{m}_{\mathrm{z}}+\left(\mathrm{H}_{\mathrm{o}}+\mathrm{H}_{\mathrm{k}}\right) \cdot \mathrm{m}_{\mathrm{L}}+\left(\mathrm{m}_{\mathrm{o}}+\mathrm{m}_{\mathrm{u}}\right)+\left(\mathrm{m}_{\mathrm{k}}+\mathrm{m}_{\mathrm{u}}\right)[\mathrm{kg}]
$$

In case that $m_{k}=m_{o}[\mathrm{~kg}]$, the relation (19) can be rewritten into the form of (20).

$$
\mathrm{m}_{\mathrm{p}}=\mathrm{m}_{\mathrm{z}}+\left(\mathrm{H}_{\mathrm{o}}+\mathrm{H}_{\mathrm{k}}\right) \cdot \mathrm{m}_{\mathrm{L}}+2 \cdot \mathrm{m}_{0}+2 \cdot \mathrm{m}_{\mathrm{u}}[\mathrm{kg}]
$$

\begin{tabular}{|c|c|c|c|c|}
\hline \multicolumn{5}{|c|}{ Weight of the weights in mining vessel $m_{z}=0 \mathrm{~kg}$} \\
\hline $\begin{array}{l}\text { Measuring } \\
\text { No. }\end{array}$ & $\begin{array}{l}\text { Depth of 1st } \\
\text { vessel } H_{0}[\mathrm{~m}]\end{array}$ & $\begin{array}{c}\text { Depth of 2st vessel } \\
\mathrm{H}_{\mathrm{k}}[\mathrm{m}]\end{array}$ & $\begin{array}{c}\text { Travel } \\
\text { time } t_{j} \\
{[\mathrm{~m} / \mathrm{s}]}\end{array}$ & $\begin{array}{c}\text { Distance } \\
\text { moved 1st } \\
\text { vessel } h_{0}[\mathrm{~m}]\end{array}$ \\
\hline L1 & 471,16 & 353,14 & 18,82 & 2,36 \\
\hline L2 & 472,26 & 353,04 & 27,66 & 4,47 \\
\hline L3 & 471,85 & 353,45 & 49,28 & 5,13 \\
\hline L4 & 475,58 & 349,72 & 9,88 & 1,40 \\
\hline & $\begin{array}{c}\text { Max. speed } \\
\text { vessels } v_{n}[\mathrm{~m} / \mathrm{s}]\end{array}$ & $\begin{array}{c}\text { Total motion } \\
\text { resistance } O_{\mathrm{pa}}[\mathrm{N}]\end{array}$ & \multicolumn{2}{|c|}{$\begin{array}{c}\text { Total motion resistance } \\
\mathrm{O}_{\mathrm{pb}}[\mathrm{N}]\end{array}$} \\
\hline L1 & 0,29 & 8564,62 & \multicolumn{2}{|c|}{4151,63} \\
\hline $\mathrm{L} 2$ & 0,41 & 8651,70 & \multicolumn{2}{|c|}{4238,71} \\
\hline L3 & 0,37 & 8592,19 & \multicolumn{2}{|c|}{4179,20} \\
\hline L4 & 0,24 & 9133,56 & \multicolumn{2}{|c|}{4720,57} \\
\hline
\end{tabular}

Table 3. Data obtained by experimental measurements L1 to L12.

\begin{tabular}{|c|c|c|c|c|}
\hline \multicolumn{5}{|c|}{ Weight of the weights in mining vessel $m_{z}=1000 \mathrm{~kg}$} \\
\hline $\begin{array}{l}\text { Measuring } \\
\text { No. }\end{array}$ & $\begin{array}{c}\text { Depth of 1st } \\
\text { vessel } H_{0}[\mathrm{~m}]\end{array}$ & $\begin{array}{c}\text { Depth of 2st vessel } \\
\mathrm{H}_{\mathbf{k}}[\mathrm{m}]\end{array}$ & $\begin{array}{c}\text { Travel } \\
\text { time } \mathbf{t}_{\mathbf{j}} \\
{[\mathrm{m} / \mathbf{s}]}\end{array}$ & $\begin{array}{c}\text { Distance } \\
\text { moved 1st } \\
\text { vessel } h_{0}[\mathrm{~m}]\end{array}$ \\
\hline L5 & 401,07 & 424,22 & 61,40 & 61,02 \\
\hline L6 & 402,00 & 423,30 & 61,96 & 60,82 \\
\hline & $\begin{array}{c}\text { Max. speed } \\
\text { vessels } v_{n}[\mathbf{m} / \mathbf{s}]\end{array}$ & $\begin{array}{c}\text { Total motion } \\
\text { resistance } \mathrm{O}_{\mathrm{pa}}[\mathrm{N}]\end{array}$ & \multicolumn{2}{|c|}{$\begin{array}{c}\text { Total motion resistance } \\
\mathrm{O}_{\mathrm{pb}}[\mathrm{N}]\end{array}$} \\
\hline L5 & 3,19 & 8126,76 & \multicolumn{2}{|c|}{3713,68} \\
\hline L6 & 3,18 & 8260,93 & \multicolumn{2}{|c|}{3895,87} \\
\hline
\end{tabular}

\begin{tabular}{|c|c|c|c|c|}
\hline \multicolumn{5}{|c|}{ Weight of the weights in mining vessel $m_{z}=2000 \mathrm{~kg}$} \\
\hline $\begin{array}{l}\text { Measuring } \\
\text { No. }\end{array}$ & $\begin{array}{l}\text { Depth of 1st } \\
\text { vessel } H_{0}[\mathrm{~m}]\end{array}$ & $\begin{array}{c}\text { Depth of 2st vessel } \\
\mathbf{H}_{k}[\mathrm{~m}]\end{array}$ & $\begin{array}{l}\text { Travel } \\
\text { time } t_{j} \\
{[\mathbf{m} / \mathbf{s}]}\end{array}$ & $\begin{array}{c}\text { Distance } \\
\text { moved 1st } \\
\text { vessel } h_{0}[\mathrm{~m}]\end{array}$ \\
\hline L7 & 351,42 & 474,02 & 22,40 & 32,25 \\
\hline L8 & 360,77 & 464,67 & 21,76 & 30,34 \\
\hline L9 & 337,90 & 487,54 & 29,74 & 41,84 \\
\hline & $\begin{array}{c}\text { Max. speed } \\
\text { vessels } v_{n}[\mathrm{~m} / \mathrm{s}]\end{array}$ & $\begin{array}{c}\text { Total motion } \\
\text { resistance } \mathrm{O}_{\mathrm{pa}}[\mathrm{N}]\end{array}$ & \multicolumn{2}{|c|}{$\begin{array}{l}\text { Total motion resistance } \\
\mathrm{O}_{\mathrm{pb}}[\mathrm{N}]\end{array}$} \\
\hline L7 & 2,62 & 10716,31 & \multicolumn{2}{|c|}{6303,22} \\
\hline L8 & 3,10 & 12070,36 & \multicolumn{2}{|c|}{7660,37} \\
\hline L9 & 3,21 & 8754,04 & \multicolumn{2}{|c|}{4341,05} \\
\hline
\end{tabular}

\begin{tabular}{|c|c|c|c|c|}
\hline \multicolumn{5}{|c|}{ Weight of the weights in mining vessel $\mathbf{m}_{\mathbf{z}}=\mathbf{3 0 0 0} \mathbf{~ k g}$} \\
\hline Measuring No. & $\begin{array}{c}\text { Depth of 1st } \\
\text { vessel } \mathbf{H}_{\mathbf{0}}[\mathbf{m}]\end{array}$ & $\begin{array}{c}\text { Depth of 2st vessel } \\
\mathbf{H}_{\mathbf{k}}[\mathbf{m}]\end{array}$ & $\begin{array}{c}\text { Travel } \\
\text { time } \mathbf{t}_{\mathbf{j}} \\
{[\mathbf{m} / \mathbf{s}]}\end{array}$ & $\begin{array}{c}\text { Distance } \\
\text { moved 1st } \\
\text { vessel } \mathbf{h}_{\mathbf{o}}[\mathbf{m}]\end{array}$ \\
\hline L10 & 297,11 & 528,45 & 14,66 & 21,25 \\
\hline
\end{tabular}




\begin{tabular}{|c|c|c|c|c|}
\hline L11 & 248,83 & 576,71 & 21,38 & 31,01 \\
\hline L12 & 190,68 & 634,81 & 81,10 & 72,38 \\
\hline & $\begin{array}{c}\text { Max. speed } \\
\text { vessels vn } \\
{[\mathbf{m} / \mathbf{s}]}\end{array}$ & $\begin{array}{c}\text { Total motion } \\
\text { resistance } \mathbf{O}_{\mathbf{p a}}[\mathbf{N}]\end{array}$ & $\begin{array}{c}\text { Total motion resistance } \\
\mathbf{O}_{\mathbf{p b}} \text { [N] }\end{array}$ \\
\hline L10 & 3,15 & 12631,79 & 8218,8 \\
\hline L11 & 3,12 & 5625,23 & 1212,24 \\
\hline L12 & 3,19 & 2816,02 & 7229,01 \\
\hline
\end{tabular}

For known values (see Table 3, line L1), the value of the total mass of the sliding mass $\mathrm{m}_{\mathrm{p}}[\mathrm{kg}]$ can be determined, see the relation (21).

$$
\begin{aligned}
\mathrm{m}_{\mathrm{p}} & =\mathrm{m}_{\mathrm{z}}+\left(\mathrm{H}_{\mathrm{o}}-\mathrm{H}_{\mathrm{k}}\right) \cdot \mathrm{m}_{\mathrm{L}}+2 \cdot\left(\mathrm{m}_{\mathrm{o}}+\mathrm{m}_{\mathrm{u}}\right)=0+(471,16-353,14) \cdot 7,4+ \\
& +2 \cdot(1720+62)=118,02 \cdot 7,4+2 \cdot 1782=873,35+3564=4437,35 \mathrm{~kg}
\end{aligned}
$$

By substituting the maximum transport vessels speed achieved in $[\mathrm{m} / \mathrm{s}]$ and the travel time, ie [s] according to Table 3 line L1, it is possible to determine the component of the inertial force of the sliding masses $\mathrm{F}_{\mathrm{dp}}[\mathrm{N}]$ in the relation (21) using the relation (18), specifically, see relation (22).

$$
\mathrm{F}_{\mathrm{dp}}=\mathrm{m}_{\mathrm{p}} \cdot \frac{\mathrm{v}}{\mathrm{t}_{\mathrm{j}}}=4437,35 \cdot \frac{\mathrm{v}}{\mathrm{t}_{\mathrm{j}}}=4437,35 \cdot \frac{0,29}{18,82}=4437,35 \cdot 0,015=66,56 \mathrm{~N}
$$

From the relation (16), the dynamic force of the rotating mass $\mathrm{F}_{\mathrm{dr}}[\mathrm{N}]$ can be determined at the calculated values, see (23).

$$
F_{d r}=F-F_{s}-F_{d p}=8564,62-8320,66-66,56=177,4 N
$$

By substituting the value of the inertial force component of the sliding masses $F_{d p}[N]$ from the relation (22) to the relation (17), it is possible to get the value of the reduced moment of inertia of the winder rotary parts $\mathrm{Jr}\left[\mathrm{kg} . \mathrm{m}^{2}\right]$, see the relation (24), at the known radius of the winder drum $R_{b}=2 \mathrm{~m}$.

Chyba! Objekty sa nedajú vytvorit’ úpravami kódov polí.

According to the materials provided from the production documentation of the winder, it is known that the actual value of inertia moment of the two rope drums, including the shaft of the mining equipment, is $J_{b s}=71.2103 \mathrm{~kg} . \mathrm{m}^{2}$. Shaft weight $\mathrm{m}_{\mathrm{h}}=8600 \mathrm{~kg}$ and weight of both rope drums $m_{b s}=29560 \mathrm{~kg}$. From these known values, it is possible to determine, according to the relation (25), the actual dynamic moment of rotating masses $\mathrm{M}_{\mathrm{drs}}[\mathrm{N} . \mathrm{m}]$ and according to the relation (26) to determine the real dynamic force of the rotating masses $\mathrm{F}_{\mathrm{drs}}[\mathrm{N}]$ and compare it with the calculated dynamic force of the rotating masses $F_{d r s}[N]$, see the relation (23).

$$
\begin{gathered}
\mathrm{M}_{\mathrm{drs}}=\mathrm{J}_{\mathrm{bs}} \cdot \varepsilon=\mathrm{J}_{\mathrm{bs}} \cdot \frac{\mathrm{a}}{\mathrm{R}_{\mathrm{b}}}=71,2 \cdot 10^{3} \cdot \frac{0,015}{2}=71,2 \cdot 10^{3} \cdot 7,5 \cdot 10^{-3}=534 \mathrm{~N} \cdot \mathrm{m}(25) \\
\mathrm{M}_{\mathrm{drs}}=\mathrm{F}_{\mathrm{drs}} \cdot \mathrm{R}_{\mathrm{b}} \Rightarrow \mathrm{F}_{\mathrm{drs}}=\frac{\mathrm{M}_{\mathrm{drs}}}{\mathrm{R}_{\mathrm{b}}}=\frac{534}{2}=267 \mathrm{~N}
\end{gathered}
$$




\section{Conclusion}

The report describes a unique experimental measuring, which was carried out on the mining equipment No. 1 of the down-cast air shaft No. 5 of the Mining Plant 1, the Lazy Mine location, which is equipped with a two-drum winder. The uniqueness of the measurement carried out was that during the experiment, the drive engine was decommissioned and all safety features of the mining equipment were blocked in order to allow the movement of the mining cages through the pit only by its own weight when the static resistances of the mining equipment were overcome.

From the deducted values, from the control panel in the engine room of the mining equipment, the initial positions of the mining vessels, the known weight of the two mining cages and the weight of the mining rope, the maximum static resistance was determined, which, in the normal operation of the mining equipment, exceeds the drive engine as one of the motion resistance components. The static resistance determined by this experiment is determined only as the rolling resistance of the sliding bearings of the rope drum shaft, and the resistance of the roller bearings of the ropes, where both ropes are guided into the pit, has not been taken into account.

The second part of the experimental measurement, based on the values obtained by measuring of the travelled trajectory and the instantaneous speed of the mining cage and the known initial positions of the mining vessels, was intended to determine the dynamic resistance that occurs during the start of the mining equipment engine.

The total motion resistance determined by calculation does not take into account other resistances normally encountered during the operation of the mining equipment, such as air resistance, friction resistance (sliding or rolling) of the mining crane against the guide [9-10].

\section{References}

1. P. Peterka, J. Krešak, S. Kropuch, G. Fedorko, V. Molnár and M. Vojtko: Engineering Failure Analysis 45, 96 -105, (2014)

2. J. Leinveber, P. Vávra, Strojnické tabulky, (ALBRA, 2006)

3. L. Hrabovský, H. Gondek: Biblioteka TEMAG. Ustroń 19. - 21. ř́́jen 2017, str. 55 66. ISBN 978-83-65547-09-5

4. M. Straka, A. Rosová and G. Fedorko: TU - 2013. - 72 s. [CD ROM]. - ISBN 978-80553-1520-1

5 Hrabovský: Prague 12-16. June 2017. ISSN 1757-899X/245

6 J. Houdek: Investigation, production and use of steel wire ropes, conveyers and hoisting machines, (Original in Czech), 177-180, (2014)

7 L. Hrabovský: Adv. Sci. Technol. Res. J. 11, 4, 326-332, (2017)

8 L. Hrabovský, H. Gondek: XXV Miedzinarodowa konferencja naukowo techniczna. Biblioteka TEMAG. Ustroń, 45-54 (2017)

9. V. Molnar, G. Fedorko, J. Kresak, P. Peterka, J. Fabianova, Eng. Fail. Anal. 74, 119132 (2017)

10. J. Kulka, M. Mantic, G. Fedorko, V. Molnar, Eng. Fail. Anal. 59, 384-395 (2016) 